\title{
Association of Serum Hyaluronic Acid and Laminin with Polymerase Chain Reaction Findings in Hepatitis C Patients
}

\author{
Tahir Asad, Muhammad Aamir, Zujaja Hina Haroon, Sobia Irum Kirmani, Muhammad Usman Munir and Syed \\ Raza Jaffar
}

Department of Chemical Pathology and Endocrinology, Armed Forces Institute of Pathology, Rawalpindi, Pakistan

\begin{abstract}
Objectives: To find the association of serum hyaluronic acid and laminin levels with polymerase chain reaction (PCR) results in hepatitis $\mathrm{C}$ sero-positive patients; and the correlation among viral load, serum hyaluronic acid, and serum laminin levels.

Study Design: Cross-sectional descriptive study.

Place and Duration of Study: Department of Chemical Pathology and Endocrinology, Armed Forces Institute of Pathology (AFIP), Rawalpindi, Pakistan from December 2019 to July 2020.

Methodology: One hundred and eighty diagnosed cases of hepatitis C patients were included in this study. To find association, cross tabulation was done after dividing into two groups according to their median by applying Chi-square test. Correlation of viral load, duration of disease, serum hyaluronic acid and laminin levels were calculated using Spearman's correlation.

Results: There were 124 (68.9\%) males and 56 (31.1\%) females. Median (IQR) age was 36 (32.3 - 45.0) years; while median duration of disease was 12 ( 8 - 18) months. There was a strong association between PCR positive cases with hyaluronic acid ( $p<0.001$ ) and serum laminin levels $(p<0.001)$. A strong relationship was found between viral load and serum hyaluronic acid $(r=0.889, p$ $<0.001)$, as well as with serum laminin ( $r=0.889, p<0.001)$.

Conclusion: Current study established a strong significant association between PCR results and disease duration with levels of serum laminin and hyaluronic acid. The levels of serum laminin and serum hyaluronic acid also correlate well with viral load and duration of disease.
\end{abstract}

Key Words: Hepatitis C, Hepatic fibrosis, Hyaluronic acid, Laminin.

How to cite this article: Asad T, Aamir M, Haroon ZH, Kirmani SI, Munir MU, Jaffar SR. Association of Serum Hyaluronic Acid and Laminin with Polymerase Chain Reaction Findings in Hepatitis C Patients. J Coll Physicians Surg Pak 2021; 31(05):528-531.

\section{INTRODUCTION}

Hepatitis $C$ is an aggressively spreading worldwide health problem. ${ }^{1}$ One hundred and seventy million active hepatitis $C$ carriers have been reported worldwide, with three to four million new cases reported each year. ${ }^{2}$ Progression to chronic liver disease occurs in $85 \%$ of the cases. Chronic hepatitis C infection causes persistent inflammation in the liver, progression to hepatic fibrosis, eventually to cirrhosis, and possible hepatocellular carcinoma, which will ultimately lead to liverfailure and death. ${ }^{3}$

The hallmark of hepatic fibrosis is a collection of increased extracellular matrix components. It may result from microscopic rearrangement of collagens, proteoglycans, non-collagenous glycoproteins such as hyaluronic acid (HA) and laminin (LN). ${ }^{4}$

Correspondence to: Dr. Tahir Asad, Department of Chemical Pathology and Endocrinology, Armed Forces Institute of Pathology, Rawalpindi, Pakistan

E-mail: asadghazi@gmail.com

Received: January 01, 2021; Revised: March 16, 2021;

Accepted: March 30, 2021

DOI: https://doi.org/10.29271/jcpsp.2021.05.528
The main mechanism behind liver fibrosis is the dysregulation of the decomposition and its removal of the extracellular matrix. The main fibrogenic cells are hepatic stellate cells (HSCs), involved in the control of synthesis and degradation of both extracellular matrix. Production of cytokines such astransforming growth factor $\beta 1$ and alpha is linked to increased stimulation and production of these hepatic stellate cells. ${ }^{5}$

HA is synthesised by HSCs and highly controlled synovial lining cells. Hyaluronic-acid synthase involved for HA production, are located at membranes of the hepatic cells. Degradation of HA is normally done by sinusoidal endothelial cells by a precisely controlled process involving hyaluronidase, glucuronidase, and acetyl hexosaminidase. The most widely expressed hyaluronidases cleave high molecular weight HA into smaller oligosaccharides. For an effective fibrosis marker, the development of $\mathrm{HA}$, its release into the sinusoidal blood circulation, and a half-life of 2-9 minutes in blood are good inferences. ${ }^{6}$ Therefore, an elevated serum HA concentration may be related to impaired clearance and degradation by the liver cells. Hepatitis $C$ patients and those suffering from liver diseases exhibit increased levels of serum HA levels. In basement membrane, $\mathrm{LN}$ are most important among various glycoproteins. It is 
produced by sinusoidal cells and hepatocytes. ${ }^{7}$ The principal amount of serum LN is produced by stellate cells or lipocytes. In patients with advanced stage fibrosis, serum LN levels are typically found to increase in chronic liver disease. ${ }^{8}$

Measuring the serum levels of LN could provide a non-invasive and sensitive screening tool for fibrotic conditions due to hepatic diseases and portal hypertension. ${ }^{9}$ Combined with serum HA, its accuracy would be improved. In order to diagnose and rate the disease progression, it is one of the most important steps to determine the stage of hepatic fibrosis and the grade of inflammation, which in turn affects the choice of treatment modality and to research the outcome. HA and LN in serum are emerging as a potentially promising non-invasive biomarker of hepatic fibrosis in chronic patients with hepatitis $\mathrm{C}$. The aim of this study was to find the association of $\mathrm{HA}$ and LN with polymerase chain reaction results in hepatitis $C$ patients; and correlation among viral load, serum hyaluronic acid, and serum laminin levels.

\section{METHODOLOGY}

A cross-sectional descriptive study was carried out at the Department of Chemical Pathology and Endocrinology, Armed Forces Institute of Pathology (AFIP), Rawalpindi, Pakistan. The size of the sample was estimated using an online sample size calculator from Rao Soft and found to be 180 with prevalence of $13.5 \%$ at $95 \%$ confidence interval and $5 \%$ margin of error. ${ }^{10,11}$ Sampling was conducted through easy non-probability sampling and eight months of study period from December 2019 to July 2020, upon acceptance by the Institutional Review Board (IRB). Patients with hepatitis C virus (HCV) infection, confirmed by the presence of positive HCV-Ab, have been included; whereas, patients with negative HCV-Ab, other causes of hepatic fibrosis, cirrhosis, hepatocellular carcinoma or other solid tumors, history of interferon or ribavirin therapy, and conditions such as autoimmune diseases (e.g. R.A and SLE), in which HA may be elevated, were excluded from the study.

After IRB approval, patient identification, informed consent and detailed history, blood samples were collected from the participants in EDTA tube for HCV ribonucleic acid (RNA), and in gel tubes for serum HA and LN levels. Serum HA and serum LN were analysed on fully automated chemiluminescence immunoassay analyser (Maglumi 800 by Snibe Diagnostics, China); and polymerase chain reaction (PCR) for HCV RNA was analysed on SaCycler-96 Real Time PCR system by Sacace Biotechnologies, Italy.

Data was analysed through SPSS version 21. Data normality was checked using Kolmogorov-Smirnov test, which showed a non-parametric distribution of data. Frequencies and percentages were obtained for qualitative variables and median (IQR: 25th percentile-75th percentile) for quantitative variables, while difference between PCR findings with medians of $L N$ and HA was found through Mann-Whitney U-test. To find association between PCR findings with $L N$ and $H A$, cross tabulation was done after dividing into two groups, according to their median using Chi-square test. Statistical p-value of less than 0.05 was taken significant and relationship among variables were checked through Spearman's correlation.

\section{RESULTS}

Among a total of 180 patients of Hepatitis C virus infection, 124 (68.9\%) were males and 56 (31.1\%) females. Median (IQR) age of the patients was $36(32.3-45.0)$ years with median disease duration of 12 (8 - 18) months. Median (IQR) of serum HA 168.7 (86.3 - 356.2) ng/ml, LN $114.3(56.8-245.0) \mathrm{ng} / \mathrm{ml}$ and viral load was 21804001(3693.0-53958989165.8) IU/ml.

Among all the patients, there were 136 (75.6\%) PCR positive cases, while 44 (24.4\%) were PCR negative cases. The difference between medians of laminin and hyaluronic acid with PCR positive and PCR negative cases were compared and found to besignificant (both $p<0.001$ ) (Tablel).

Table I: Comparison between median (IQR) values of HA and LA levels in PCR positive and negative patients.

\begin{tabular}{|l|c|c|c|}
\hline Variables & $\begin{array}{c}\text { PCR Positive } \\
(\mathbf{n = 1 3 6 )}\end{array}$ & $\begin{array}{c}\text { PCR Negative } \\
(\mathbf{n = 4 4 )}\end{array}$ & p-value \\
\hline $\begin{array}{l}\text { Hyaluronic acid ng/ml } \\
\text { [median (IQR)] }\end{array}$ & $155.5(93.1-263.4)$ & $40.7(30.6-46.7)$ & $<0.001$ \\
\hline $\begin{array}{l}\text { Laminin } \mathrm{ng} / \mathrm{ml} \\
\text { [median (IQR)] }\end{array}$ & $270.3(126.8-367.9)$ & $68.2(60.0-76.9)$ & $<0.001$ \\
\hline
\end{tabular}

Table II: Association between PCR findings with laminin and hyaluronic acid.

\begin{tabular}{|l|c|c|c|}
\hline Groups & PCR positive & PCR negative & p-value \\
\hline Laminin (ng/ml) & $48(35.3 \%)$ & $42(95.5 \%)$ & \multirow{2}{|l|}{$<0.001$} \\
\hline Less than median $(<114.3)$ & $88(64.7 \%)$ & $2(4.5 \%)$ & \\
\hline Equal or more than median $(>114.3)$ & & \\
\hline Hyaluronic acid $(\mathrm{ng} / \mathrm{ml})$ & $47(34.6 \%)$ & $43(97.7 \%)$ & \multirow{2}{|l|}{$<0.001$} \\
\hline Less than median $(<168.7)$ & $89(65.4 \%)$ & $1(2.3 \%)$ & \\
\hline Equal or more than median $(>168.7)$ &
\end{tabular}

The association was assessed after dividing $\mathrm{LN}$ and $\mathrm{HA}$ into two groups, according to their median, which showed a strong association between PCR findings and LN ( $p$-value $<0.001$ ) and hyaluronic acid ( $p$-value $<0.001)$. The outcomes are presented in Table Il.

Spearman's correlation showed a strong positive correlation between serum HA-viral load $(r=0.889, p<0.001)$, and LN-viral load $(r=0.889, p<0.001)$, $(r=0.889, p<0.001)$. A strong positive correlation was also observed between serum HA-disease duration $(r=0.824, p<0.001)$ and serum $L N$-disease duration $(r=0.832, p<0.001)$.

\section{DISCUSSION}

Liver fibrosis is the stage that is led by continuous inflammatory process during chronic hepatitis C. Liver fibrosis ultimately leads to cirrhosis among $10-40 \%$ of cases over the decades. The most challenging events of hepatic cirrhosis are ascites, varices in esophagus, hepatic carcinoma, and eventually, liver failure and death. Significantly, cirrhosis may evolve to hepatic carcinoma with a 1-5 percent annual incidence, and mortality due to cirrhosis complications occurs at 4 percent annual incidence. ${ }^{12}$ HA, LN, collagens, proteoglycans and fibronectin are the extracellular matrix that accumulates and lead towards liver fibrosis. 
Biopsy has been considered to be the gold standard for evaluating liver fibrosis. However, because of its inherent limits, its intrusiveness such as error in sampling (approximately $1 / 50,000$ th of liver tissue is obtained), non-reproducible sample quality depending on the size of the tissue sample coefficient of variation (CV) of 35-45 percent, and a microscopic examination precisely depending on the experience of the Histopathologist, various noninvasive procedures have now materialised as potential forefront investigations. ${ }^{13}$ These may include different serum or plasma based biological markers of fibrosis and physical approaches (ultrasound, magnetic resonance elastrography).

Younesi et al. in a study compared the analytical performance of the glycoproteins and the area under the curves for $\mathrm{HA}, \mathrm{LN}$; and the fibronectin serum levels were 0.820 .89 and 0.73 , respectively. ${ }^{14}$ Quantitative evaluation of HA can lead to the knowledge of how much progressive liver damage has occurred as there seems to be direct relation between levels of $\mathrm{HA}$ in different chronic hepatic disorders. ${ }^{15}$

There was a strong association in this study between serum HA and LN levels in patients with hepatitis C virus infection. Positive HCV PCR patients with higher viral load and extended disease duration had higher serum HA and LN levels depicted greater extent of hepatic fibrosis as compared to negative HCV PCR cases and less disease duration.

A study conducted by Akram et al. concluded in contrast to the control group, HA levels were found to be two times higher among people infected with hepatitis $\mathrm{C}^{16}$ Murawaki et al. have reported statistically significant variations in $\mathrm{HA}$ levels in chronic hepatitis $C$ patients at different stages of hepatic fibrosis. ${ }^{17}$ Tao et al. also reported the higher levels of serum HA and LN among cases and controls of cirrhotic patients as the stages of fibrosis advances. ${ }^{18}$ In a study conducted by ElMezayen et al., it was found that patients with extreme liver fibrosis had a higher mean serum level of $L N$ relating to those with mild liver fibrosis and also demonstrated appropriate discriminatory prognosis of severe hepatic fibrosis, and cirrhosis, with area under curve (AUC) of 0.831 and $0.881 .^{19}$

Lydatakis et al. showed that $\mathrm{HA}$ is a strong fibrosis marker with a sensitivity of 86-100 percent, an 88 percent specificity and a receiver operating characteristics (ROC) of 0.97 in non-alcoholic fatty liver disease and other in causes. ${ }^{20}$ Another study carried out by Persian et al. reported strong correlation between LN and HA concentrations with hepatic necro-inflammatory lesions. ${ }^{21}$ In hepatic fibrosis, serum HA and LN readings rise and may be used as a non-invasive biomarker to differentiate between liverfibrosis patients and healthy people.

A study performed by Walsh et al. concluded that both LN and type IV collagen in serum were associated with necro-inflammatory injury scores and fibrotic stage. ${ }^{22}$ A research performed by Khan et al. showed a clear relationship between serum $\mathrm{HA}$ and liver fibrosis levels. As fibrosis in liver progresses, HA levels rise accordingly and levels are higher in patients with cirrhosis. It displayed a relatively strong sensitivity of 78.4 per cent, a precision of 80.9 per cent, a positive predictive value of 93.9 per cent, and a negative predictive value of 50 percent. ${ }^{23}$

Xian-jun Ding found a strong relation between the serum LN and $\mathrm{HA}$ levels and the inflammatory activity grades histologically measured $(r=0.394$ and 0.449 respectively, $p<0.01){ }^{24}$ ElSaeid et al. indicated that serum laminin measurements can distinguish between patients with liver fibrosis and healthy individuals; and between extreme fibrosis and moderate fibrosis relating to otherindicators of fibrosise.g. APRI and Fibro Q. ${ }^{25}$

The diagnosis, staging, and prognosis of chronic liver diseases are important in addressing the global burden of disease. The findings of this study are in well agreement with various studies conducted in variety of environment settings. These extensive findings of $\mathrm{HA}$ and LN levels with viral load are in agreement, to play a significant role in the early prediction of liver fibrosis, particularly when liver biopsy is not an option. Although the study provides guidance for selecting a non-invasive biochemical marker for assessing liver fibrosis, a multicentered approach with larger sample size will further strengthen the findings.

\section{CONCLUSION}

The present findings indicate that there is substantial difference between HCV PCR positive and HCV PCR negative cases with levels of serum LN and HA. The levels of serum LN and HA are well correlated with viral load and length of disease. Thus, along with other recent developments, it can be an additional non-invasive biomarker for the evaluation of hepatic fibrosis progression in hepatitis C patients.

\section{ETHICALAPPROVAL:}

This study was carried out after obtaining approval from the Institutional Review Board and Ethical Committee of Armed Forces Institute of Pathology (AFIP), Rawalpindi, Pakistan.

\section{PATIENTS' CONSENT:}

Informed consents were taken from all patients participated in the study.

\section{CONFLICT OF INTEREST:}

The authors declared no conflict of interest.

\section{AUTHORS' CONTRIBUTION:}

TA, MA: Data collection, data analysis, result, discussion and literature review.

ZHH, SIK, SRJ: Discussion and literature review.

MUM: Results and literature review.

\section{REFERENCES}

1. Petruzziello A, Marigliano S, Loquercio G, Cozzolino A, Cacciapuoti C. Global epidemiology of hepatitis C virus infection: An up-date of the distribution and circulation of hepatitis C virus genotypes. World J Gastroenterology 2016 22(34):7824. doi: 10.3748/wjg.v22.i34.7824.

2. Umer $M$, Iqbal $M$. Hepatitis $C$ virus prevalence and genotype distribution in Pakistan: Comprehensive review 
of recent data. World J Gastroenterol 2016; 22(4):1684. doi: 10.3748/wjg.v22.i4.1684.

3. Singer AW, Reddy KR, Telep LE, Osinusi AO, Brainard DM, Buti $M$, et al. Direct-acting antiviral treatment for hepatitis $C$ virus infection and risk of incident liver cancer: a retrospective cohort study. Alimentary Pharmacology Therapeutics 2018; 47(9):1278-87. doi: 10.1111/apt. 14593.

4. Gressner AM, Gao CF, Gressner OA. Non-invasive biomarkers for monitoring the fibrogenic process in liver: $A$ short survey. World J Gastroenterol 2009; 15(20):2433. doi: 10.3748/wjg.15.2433.

5. Friedman SL. Hepatic stellate cells: Protean, multifunctional, and enigmatic cells of the liver. Physiol Rev 2008; 88(1):125-72. doi: 10.1152/physrev.00013. 2007.

6. Gudowska M, Cylwik B, Chrostek L. The role of serum hyaluronic acid determination in the diagnosis of liver diseases. Acta Biochim Pol 2017; 64(3):451-7. doi: 10.18388/abp.2016_1443.

7. Gressner AM, Tittor W. Serum laminin-its concentration increases with portal hypertension in cirrhotic liver disease. Klin Wochenschr 1986; 64(23):1240-8. doi: 10.1007/BF01734467. PMID: 3807271.

8. Mak KM, Mei R. Basement membrane type IV collagen and laminin: an overview of their biology and value as fibrosis biomarkers of liver disease. Anat Rec 2017; 300(8): 1371-90. doi: 10.1002/ar.23567.

9. Korner T, Kropf J, Gressner AM. Serum Iaminin and hyaluronan in liver cirrhosis: markers of progression with high prognostic value. J Hepatol 1996; 25(5):684-8. doi: 10.1016/s0168-8278(96)80239-x.

10. Satti R, Mustafa F, Imran Khan M, Sultana Haq T, Umar Khan Z, Zubair M, et al. Prevalence of hepatitis $C$ virus in urban Ghettos of twin cities. Pakistan J Zool 2012; 44(4): 937-43.

11. Al Kanaani Z, Mahmud S, Kouyoumjian SP, Abu-Raddad LJ. The epidemiology of hepatitis $C$ virus in Pakistan: Systematic review and meta-analyses. $R$ Soc Open Sci 2018; 5(4):180257. doi:10.1098/rsos.180257.

12. van der Meer AJ, Feld JJ, Hofer H, Almasio PL, Calvaruso V, Fernández-Rodríguez CM, et al. Risk of cirrhosis-related complications in patients with advanced fibrosis following hepatitis C virus eradication. J Hepatol 2017; 66(3): 485-93.

13. Younesi S, Parsian H. Diagnostic accuracy of glycoproteins in the assessment of liver fibrosis: A comparison between laminin, fibronectin, and hyaluronic acid. Turkish J Gastroenterol 2019; 30(6):524. doi: 10.5152/tjg.2019. 17339.

14. Bedossa $P$, Dargère $D$, Paradis $V$. Sampling variability of liver fibrosis in chronic hepatitis C. Hepatology 2003; 38(6):1449-57. doi: 10.1016/j.hep.2003.09.022.

15. European Association for the Study of the Liver (EASL) clinical practice guidelines: Management of hepatitis C virus infection. J Hepatol 2011; 55:245 264.

16. Akram M, Memon AR, Pushpa, Ullah F, Shafiq MI. Hyaluronic acid act asa non - invasive marker for diagnosis of liver fibrosis in the patients of ChronicHepatitis C. J LiaquatUni Med Health Sci 2018; 17(03):161-4. doi: 10.22442/jlumhs.181730570.

17. Murawaki Y, Ikuta Y, Okamoto K, Koda M, Kawasaki H. Diagnostic value of serum markers of connective tissue turnover for predicting histological staging and grading in patients with chronic hepatitis C. J Gastroenterol 2001; 36(6):399-406. doi: 10.1007/s005350170084.

18. Tao J, Peng HQ, Cai WM, Dong FQ, Weng HL, Liu RH. Influence factors of serum fibrosis markers in liver fibrosis. World J Gastroenterol 2003; 9(11):2497. doi: 10.3748/wjg. v9.i11.2497.

19. El-Mezayen HA, Habib S, Marzok HF, Saad MH. Diagnostic performance of collagen IV and laminin for the prediction of fibrosis and cirrhosis in chronic hepatitis $C$ patients: A multicenter study. Eur J Gastroenterol Hepatol 2015; 27(4):378-85. doi: 10.1097/MEG.0000000000000298.

20. Lydatakis, H, Hager LP, Kostadelou E, Mpousmpoulas S, Pappas S, Diamantis L. Non-Invasive Markers to Predict the Liver Fibrosis in Non-Alcoholic Fatty Liver Disease. Liver International 2006; 26(7):pp.864-71. doi:10.1111/ j.1478-3231.2006.01312.x.

21. Parsian H, Rahimipour A, Nouri M, Somi MH, Qujeq D, Kashi Fard $M$, et al. Serum hyaluronic acid and laminin as biomarkers in liver fibrosis. I Gastrointestinal Liver Diseases 2010; 19(2):169-74

22. Walsh KM, Fletcher A, MacSween RN, Morris AJ. Basement membrane peptides as markers of liver disease in chronic hepatitis C. J Hepatol 2000; 32(2):325-30. doi: 10.1016/ s0168-8278(00)80079-3.

23. Khan JA, Khan FA, Dilawar M, Ijaz A, Khan NA, Mehmood T. Serum hyaluronic acid as a marker of hepatic fibrosis. J Coll Physicians Surg Pak 2007; 17(6):323-6. PMID: 17623578.

24. Ding XJ, Li SB, Li SZ, Liu HS, Liu B, Xu FM, et al. A quantitative study of the relationship between levels of liver fibrosis markers in sera and fibrosis stages of liver tissues of patients with chronic hepatic diseases. ZhonghuaGanZang Bing ZaZhi 2005; 13(12):911-4. Chinese.

25. El-Saeid GK, El-Sharawy AA, Tahaa HE, Fathy WM, ElmorsyBedira IS. Assessment of laminin level and its comparison with five liver fibrosis indices in chronic hepatitis B and C patients. Menoufia Med J 2016; 29(2): 354-9. 